July 1985

\title{
The Webs we Weave: A Patient with Depression
}

Mary Ann Venezia, MD

Thomas Jefferson University Hospital

Follow this and additional works at: https://jdc.jefferson.edu/jeffjpsychiatry

Part of the Psychiatry Commons

Let us know how access to this document benefits you

\section{Recommended Citation}

Venezia, MD, Mary Ann (1985) "The Webs we Weave: A Patient with Depression," Jefferson Journal of Psychiatry. Vol. 3 : Iss. 2 , Article 9.

DOI: https://doi.org/10.29046/JJP.003.2.008

Available at: https://jdc.jefferson.edu/jeffjpsychiatry/vol3/iss2/9

This Article is brought to you for free and open access by the Jefferson Digital Commons. The Jefferson Digital Commons is a service of Thomas Jefferson University's Center for Teaching and Learning (CTL). The Commons is a showcase for Jefferson books and journals, peer-reviewed scholarly publications, unique historical collections from the University archives, and teaching tools. The Jefferson Digital Commons allows researchers and interested readers anywhere in the world to learn about and keep up to date with Jefferson scholarship. This article has been accepted for inclusion in Jefferson Journal of Psychiatry by an authorized administrator of the Jefferson Digital Commons. For more information, please contact: JeffersonDigitalCommons@jefferson.edu. 


\title{
BRIEF CLINICAL REPORTS
}

\author{
THE WEBS WE WEAVE: \\ A PATIENT WITH DEPRESSION
}

\author{
MARY ANN VENEZIA, M.D.
}

\section{INTRODUCTION}

Looking back over C.'s records, I was struck by a phrase I had used to describe her, "She really seems at a loss as to what she should do with herself." A more accurate appraisal might have reflected my own uncertainty as to how I could help C. Hospitalized eight times in eight years after serious suicide attempts, she had been treated with neuroleptics, antidepressants, psychotherapy, and been involved with a day program. Once again she was in the hospital, severely depressed following a suicide attempt. There was little the psychiatric establishment had not tried. So I taught her to knit.

\section{CASE HISTORY}

C. was a sixty-year-old black female who was transferred to the psychiatric service after being admitted to the medical ICU for an overdose of a neuroleptic and antidepressant. She had been increasingly depressed in the weeks preceding admission, complaining of difficulty falling asleep and staying asleep, decreased appetite, and constipation. She reported having problems with her youngest daughter, who she described as rebellious and impulsive. She admitted to having no interest in continuing to live.

Mental status examination revealed a very withdrawn, psychomotor retarded woman whose speech was soft, slow, and sparse. Her affect was very depressed. There were no signs of psychosis.

C.'s psychiatric history began approximately ten years earlier with the onset of depressive symptoms. Since that time, she had never been entirely symptom free, although she did experience periods of improvement. She had ten children, one of whom was an alcoholic. She had been widowed three years prior to admission after a long and relatively happy marriage.

C. stated that she still missed her husband. She denied any chronic medical problems, although several were uncovered during her hospital stay.

C. remained very withdrawn during the first week of her hospitalization. Efforts

Dr. Venezia is a fourth-year resident. 
to engage her into any interaction, including unit activities, were largely unsuccessful. Because of its low toxicity in overdose and recent reports of efficacy in depression, C. was begun on Xanax ${ }^{\circledR}$ (alprazolam). Her dosage was increased to a total of only .75 mgm. a day due to sedation.

"Talking therapy" proved difficult for this patient (and me). There were many empty silences. One of the few thoughts she did express was the desire to "do something." This prompted me to offer to teach C. how to knit, a skill which she could continue after leaving the hospital and which might provide a tangible "reward." She agreed, albeit not very enthusiastically.

C.'s knitting progressed very slowly. I never thought that a piece of wool could be so full of holes. Initially C. would knit only in my presence, but gradually she began to work independently. I learned early on to reward even her most clumsily executed attempts with praise and encouragement. C. actually began to smile occasionally and with time became more verbal during sessions.

One month after being psychiatrically hospitalized, C. was sufficiently improved to undergo transfer to the medical service, where a renal and an oral mass were investigated (and found to be benign). I continued to see her during her stay on medicine, and once weekly after she was discharged from the hospital. C. would bring her knitting to therapy and would continue working while we talked. C. showed steady improvement, and after several months Xanax ${ }^{\circledR}$, which I thought had played a limited role in her recovery, was stopped. C. gradually began to fill her life with activities other than knitting. She stopped attending a day program (for which she "no longer had time") and got her own apartment. She even considered getting a job, although she has been unable to find one. Over a period of two years she has remained symptom free- despite the intercurrent suicide of one of her daughters: "I tried many times to kill myself. I think I'll just enjoy life until the good Lord decides it's my time."

\section{DISCUSSION}

Often I have asked myself why C. got well. Was it simply the natural course of her illness? The duration of her remission and the fullness of her recovery could be explained by the vagaries of affective disease. How was it possible to even consider the possibility that learning to knit may have influenced her recovery?

A common feature of depression is withdrawal of interest in the outside world. This was certainly one of the most prominent of C.'s symptoms. Frankly, trying to engage $\mathrm{C}$. drove this inexperienced resident to distraction. On what level could I meet this elderly black woman whose life experience was so far removed from mine? Perhaps it was essential for me to relate with C. as someone other than "the doctor," to meet with her as a woman who enjoyed traditional "womanly" tasks, and to move together from this base as she began to trust (not only me, but herself as well). As C.'s knitted scarf grew, so did her confidence and self-esteem. The idea that she could create a functional object from relatively useless strands of yarn may have represented the transformation of C.'s ego into a vibrant, working self.

Knitting may have also served C. as a "transitional object." Much as a child clings 
to a blanket as a symbol of his mother's love, C. could use her knitting to endure leaving the safety of the hospital environment. She could then continue her projects at home; they would be constant reminders of the hospital and her therapist.

Learning to knit may be seen as a metaphor for C.'s recovery. Like a snail peeking out from its shell, C. tentatively began to interact with me. Her knitting was at first full of holes and clumsily executed, as were her initial attempts to relate to others. Gradually she became more skilled both at knitting and at dealing with the outside world. Ultimately she even began to teach others how to knit and made gifts of her projects.

C. has been well for two years now. She knits less frequently, and no longer attends a day program, takes psychotropics, or sees me regularly. For the time being at least, she has managed to relocate within herself those supports that have helped her maintain a sense of well being. I like to think that in some small way learning to knit may have aided her recovery.

\title{
PSYCHOTHERAPY OR PSEUDOTHERAPY?
}

\author{
LAWSON R. WULSIN, M.D. \\ With thanks to Carl Salzman, M.D., for his help \\ in supervision and with this paper.
}

What is psychotherapy? I wish I knew. Thick books and long talks still leave me wondering. Hours of patients and almost as many hours of supervision leave the question hanging. I know what ECT is and how to give a good trial of amitryptiline, but I am never quite sure if what I am offering is true psychotherapy. Admittedly I am young and have only been wet for five years. But I have had one experience in my short time that put the question in perspective by putting it backwards, that is, what is not psychotherapy, or what is pseudotherapy?

This experience of pseudotherapy put me through the wringer, just as my first several borderline patients put me through the wringer. But the borderline experience came at me with banners snapping and darts flying and blaring kazoos. This experience with pseudotherapy, in contrast, snuck up on me and had me before I knew what it was or could call it a name. The embarrassment was at times fierce, but it set me on my toes. The next time someone like my man, and I hear there are lots like him out there, raps on my psychotherapeutic door, I shall be ready.

Dr. Wulsin is a fifth-year fellow in clinical research at Massachusetts Mental Health Center in Boston. 